\title{
Examining employees creativity in commercial bank of Ethiopia Woldia branches
}

\author{
Erstu Tarko Kassa * (1)
}

\section{*Correspondence:} erstu0910@gmail.com Woldia University, Woldia, Ethiopia

\begin{abstract}
Creativity is the ability to combine unique ideas, identifying new ways, systems and products in the organization. Creative workers in the organization can transform their organization to higher level by inventing new systems. This study tried to examine employees' creativity in the bank at commercial bank of Ethiopia Woldia branches. The researcher used an institutional-based cross-sectional design and followed a mixed research approach. The researcher applied a census method to participate in respondents from four branches, which were on duty 182 employees in commercial bank of Ethiopia. The collected data were analyzed by using multiple regression method after proving the quality of the data. The study finding revealed that autonomy, supervisors' support and role ambiguity significantly affects the creativity of employees in the workplace. The remaining variables self-efficacy and job complexity have no statistically significant effect on employees' creativity in the bank.
\end{abstract}

Keywords: Employees' creativity, Autonomy, Supervisors support, Job complexity, Role ambiguity, Self-efficacy

\section{Introduction}

At the end of the twentieth century and the beginning of the twenty-first century creativity of workers and students increased in the higher education institutions, business organizations, governmental and non-governmental organizations to make active novel ideas to practical events. To use the maximum efforts of employees' mangers were faced challenges in the twenty-first century to become a competitor in stiff competition. It is known that creativity was a means to understand the intention of customers and to satisfy their needs (Beheshtifar \& Zare, 2013; Çekmecelioğlu \& Günsel, 2011; Sadeghi \& Ofoghi, 2011).

After the industrialization, organization made a paradigm shift from industry to knowledge-based to bring changes in the organizations. Creativity and innovation become the base for the success and survival of business-oriented organizations. To retain customers and to satisfy the clients, creativity within the organization was a precondition (Dehnavieh et al., 2010).

Creativity of workers is essential to bring new ways, methods, and systems in the organizations, and a worker can be an administrator, artist, business entrepreneurs,

(c) The Author(s), 2021. Open Access This article is licensed under a Creative Commons Attribution 4.0 International License, which permits use, sharing, adaptation, distribution and reproduction in any medium or format, as long as you give appropriate credit to the original author(s) and the source, provide a link to the Creative Commons licence, and indicate if changes were made. The images or other third party material in this article are included in the article's Creative Commons licence, unless indicated otherwise in a credit line to the material. If material is not included in the article's Creative Commons licence and your intended use is not permitted by statutory regulation or exceeds the permitted use, you will need to obtain permission directly from the copyright holder. To view a copy of this licence, visit http:// creativecommons.org/licenses/by/4.0/. 
community leaders, designers, educators, engineers, executive directors, inventors, medical researchers, scientists, technology innovators, or urban planners and bankers. The entire workers of the organization become creative, the organization can be a competitor in global markets, enhance operational excellence, increase efficiency, and achieve profitability and growth of the organization (Abrar, 2016; Egan, 2005). In today's complex business environments, it is clear that newly invented products become out of the market and reach at maturity level within a short period when the business organization not engaged in creativity and innovation activities (Çekmecelioğlu \& Günsel, 2011; Dehnavieh et al., 2010).

The employees' creativity plays a significant role especially for the bank industry to make active new systems and provide fast and quality services for the customers (Hassan et al., 2013). Recently, the bank sector has become fast growing in Africa and in Ethiopia. To maintain the banking sector's profitability, the individual workers' creativity becomes more relevant (Hassan et al., 2013).

Several factors may affect workers to create novel products and services in the bank. Among the factors, personal talent, functional independence, personal incentives, work environment, assigned tasks, social values, pressures, organizational motivation, organizational encouragement, lack of organizational impediments, sufficient resources, realistic workload pressure, management practices, freedom, challenging work, co-worker cohesion, supervisor support, autonomy, work pressure, clarity, innovation, physical comfort, task orientation can be the most important factors that affect the creativity of workers (Doshmanziari, 2018; ElMelegy et al., 2016; Ekmekçi \& Tekin, 2011). In the Ethiopia bank industry, researches are limited, and have not addressed the factors affecting the employees to create new ideas and innovations in this sector specifically. The other issues need to investigate in this study is that the bank industry working environment is not conducive and unable to create a motivation for workers at their work place. This study focused on which factor more likely affects the creativity of bank workers in the commercial bank of Ethiopia in Woldia branches. The researcher identifies variables that may affect the employees' creativity in the bank. The research variables identified by the researcher are autonomy, role ambiguity, self-efficacy, job complexity, and supervisor support. This study tried to examine which identified factor more affects the creativity of employees in the commercial bank of Ethiopia in Woldia four branches. The researcher also sets an objective to examine employees' creativity in the commercial bank of Ethiopia Woldia branches.

\section{Literature review}

\section{Definition of creativity}

Creativity is a human character that is able to take risks and promote holistic ideas and makes tasks easy in a complex environment (Sadeghi \& Ofoghi, 2011). As cited by Doshmanziari (2018), creativity means the ability to combine ideas uniquely or to create an affinity between ideas (Zarei, 1997). It should be novel and original that will bring relevance and usefulness to the organizations, society, and the globe (Hassan et al., 2013). Creativity is the ability to discriminate against new relationships, examine subjects from new perspectives, and form new concepts from existing information. Creativity is the ability to convey new qualities in old concepts, meanings, and ideas, or coming up with 
new ways of the organization (Beheshtifar \& Zare, 2013; Alhajri, 2018; Daemei \& Safari, 2018). As cited by Daemei and Safari (2018) creativity is inborn, not learned, but they seem to be inherent talents that can also be developed and reinforced with appropriate training (Antoniades, 1990).

There are types of creativity that are practiced by the organizations and individual level. Among the main types of creativity as mentioned by Boden (1998) combinational, exploratory, and transformational creativity are the most important types of creativity (Beheshtifar \& Zare, 2013).

According to Doshmanziari (2018) suggestion, creativity should be being new and original, solve a problem, or either fit with a situation or have a certain purpose, and enhance the durability of that innovative insight.

\section{Factors affecting creativity of workers at work place}

Previous studies indicate that several factors affect workers' creativity in the workplace. Among the factors, the following are identified in this review.

\section{Autonomy}

It can be described as independence or freedom, as of the will or one's actions. It is the degree to which an employee has freedom, independence, and discretion in carrying out the tasks of the job. Autonomy is identified as a determinant of employee creativity and ultimately job performance. The degree to which an employee has control in carrying out the tasks of the job can be a factor for creativity at the workplace (Çekmecelioğlu \& Günsel, 2011). It gives employees to make the decision and determining how to accomplish activities and enhance the creativity of employees at workplace (Hassan et al., 2013).

\section{Role ambiguity}

Role ambiguity refers to a lack of specificity and expectedness for the role, responsibility, and accountability of workers. The unclear role will lead the employee to stress and frustrate during the activities undertaken by him at the work place (Tang \& Chang, 2010).

Role conflict/ambiguity is the strangeness and incompatibility of expectations associated with the role. To enhance the creativity and innovation of workers' role should be allotted clearly for workers at work. It is helpful to manage the stress of workers, to decrease job dissatisfaction, and to tackle low performance.

The managers and supervisors should be committed to clarify the roles of workers in the workplace to increase the creative workers in the organizations (Çekmecelioğlu \& Günsel, 2011).

\section{Self-efficacy}

According to the social cognitive theory definition, self-efficacy is crucial for the daily life of human beings to accomplish activities and to attain objectives and to evaluate challenges (Agu, 2015; Jaiswal \& Dhar, 2015; Hassan et al., 2013). It can predict the behavior of workers, individuals, and the community as well (Su et al., 2017). Self-efficacy is an element of self-knowledge that is crucial for the daily life of workers (Hashim, 2020). It helps workers to retain customers with high-level contact and enhance problem-solving 
skill and creativity in the work environment of the organization (Tang \& Chang, 2010). Workers' self-efficacy has a positive relationship with the innovative behavior and creativity of the organizations (Purnama et al., 2020). It has a significant influence on the leadership of the organization and increases innovative and creative work behavior (Hakimian et al., 2016).

\section{Job complexity}

Job (complexity) is enriched with number of characteristics, such as variety (variety concerns with the degree to which the job requires the person to do different things), identity, significance autonomy, and feedback (Hassan et al., 2013). Identity refers to the degree to which a person can do the job from beginning to end with a visible outcome; significance concerns with the extent to which a job has a significant impact on others-both inside and outside the organization; autonomy which is the amount of freedom and independence employee has in making decisions and determining how to do the job; feedback refers to the degree to which the job provides the employee with clear and direct information about job outcomes and performance (Rizzo et al., 1970; An et al., 2015).

\section{Supervisors support}

The previous study result indicates that the supervisor's support plays a substantial role in employees' creativity in the workplace. When the supervisors are able to provide frequent feedback for the workers, it will improve the skills employees and enhance the creativity within the organization. The supervisors should be conscious to find new ways and procedures for creativity (Hassan et al., 2013).

\section{Conceptual framework of the study}

Based on the discussion from the above sections, the researcher proposed the following study framework (Fig. 1).

\section{Materials and methods}

The researcher used institutional-based cross-sectional research design to conduct this study, because the data were collected at one shot of time in the bank's branches. Regarding the research approaches, the researcher applied mixed (quantitative and qualitative) research approaches.

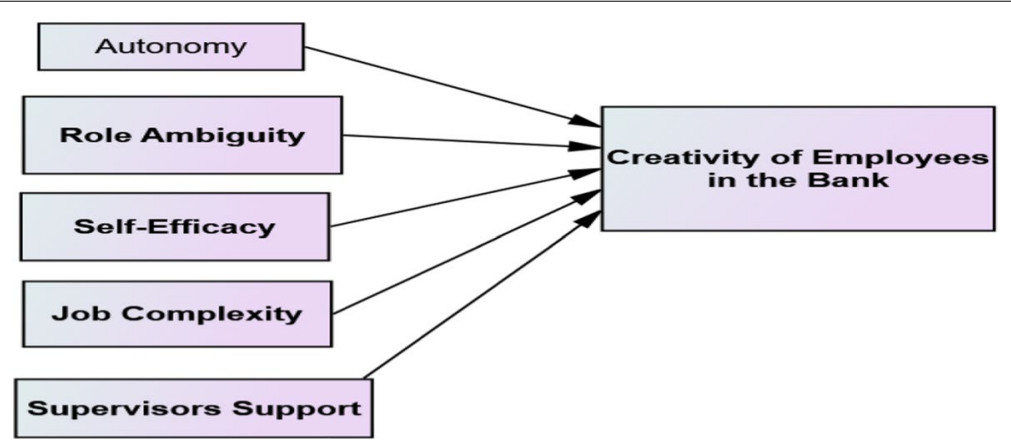

Fig. 1 Conceptual framework of the study ( source: proposed by the researcher (2020)) 
The target population that participated in the study was workers, managers and other staffs who work in Woldia city administration commercial bank four branches. In all branches, 182 workers are on duty. To undertake this study, the researcher used the census method. The reason that the researcher used census method was the total population is small, which is below 200. To apply regression analysis techniques, the sample size should be sufficient and reasonable to reach best conclusion. The details of the target population are given in Table 1 .

Regarding the instruments of the study, the questionnaires of the study variables were adapted from different authors. The dependent variable employees creativity, and the independent variables autonomy, and supervisors support adopted with some modification from Ekmekçi and Tekin (2011), role ambiguity adopted from Rizzo et al. (1970), self-efficacy from Riggs et al. (1994), and job complexity instruments were adapted from Morgeson and Humphrey (2006). All questionnaires were reversed from negative to positive after adapting from the authors. The questionnaire contains a five-point Likert scale from strongly disagree $=1$ to strongly disagree $=5$.

\section{Regression model specification and analysis}

The data were analyzed by using descriptive analysis, correlation analysis and multiple regression analysis by using SPSS version 22. The model of the study described as follows the formula given by Wooldridge (2013):

$$
Y=\beta_{0}+\beta_{1} X_{1}+\beta_{2} X_{2}+\beta_{3} X_{3}+\beta_{4} X_{4}+\beta_{5} X_{5} \cdots \beta_{k} X_{k}+\mu
$$

where $\beta_{0}$ is the intercept. $\beta_{1}$ is the parameter associated with $X_{1}$. $\beta_{2}$ is the parameter associated with $X_{2}$, and so on.

Therefore, the study model is:

$Y=$ Creativity, $X_{1}=$ Autonomy, $X_{2}=$ Role ambiguity, $X_{3}=$ Self-efficacy, $X_{4}=$ Job complexity, and $\mathrm{X}_{5}=$ Supervisors support.

\section{Ethical issues of the study}

A permission letter was submitted to the Ethiopia commercial bank main branch in Woldia city a letter written by the faculty of business and economics dean. After communication was conduct branch representatives, the data collection procedures were started. The respondents gave verbal consent for their colleagues who were volunteer to collect the data of the study. The collected data were confidential and the privacy of respondents was maintained.

Table 1 Target population of the study. Source: respective branch manager (2020)

\begin{tabular}{lc}
\hline Bank branches in Woldia City & $\begin{array}{c}\text { Target } \\
\text { population }\end{array}$ \\
\hline Piaza Branch & 64 \\
Adago Branch & 55 \\
Guba Lafto Branch & 39 \\
Yeju Genet Branch & 24 \\
Total & 182 \\
\hline
\end{tabular}




\section{Results and discussion \\ Descriptive analysis of the study \\ Response rate}

From the total dispatched 182 questionnaires 159 were returned. The remaining 23 questionnaires were not utilized for analysis purpose, because 11 responses were disqualified and 12 were not returned by respondents. The total response rate was $87.36 \%$.

\section{Reliability test of the study instruments}

To check the consistency and stability of the collected data, the reliability test is crucial. In this regard, the reliability test was conducted for four independent variables and the dependent variable of the study. Table 2 data stated that the Cronbach's alpha value for autonomy, supervisor support, role ambiguity, self-efficacy, job complexity, and employees' creativity are $.853, .822, .637, .825, .845$ and .795 , respectively. As stated by Zikmund (2011), scales with a constant between .80 and .95 are considered to have very good reliability. Scales with a constant between .70 and .80 are considered to have good reliability, and a value between .60 and .70 indicates fair reliability. Therefore, the study variables reliability is above .6 which is a fair and above reliability result as stated by Zikmund. Thus, it is evident that all prepared questionnaires were able to measure the overall organization performance and were able to make reliable data collection procedures.

\section{Analysis of demographic variables of the study}

As shown in Table 3, from the total respondents $17.6 \%$ were female and the remaining $82.4 \%$ male. Regarding the age of respondents, $2.5 \%$ of the respondents' are aged below 25 years; $64.2 \%$ between 25 and 34; $32.7 \%$ of respondents between 34 and 45 ; and $.6 \%$ of the respondents' age between 45 and 54 years. The experiences of workers in the bank branches from the year 2-6 year accounts for $73.6 \%$ of the total respondents, the remaining .6\% have below 2 years' experience and 25.8 of workers above 6 years.

From the total respondents, $1.3 \%$ are branch managers, $4.4 \%$ business managers, $15.7 \%$ senior banking business officers, 61\% banking business officers, $16.4 \%$ business operation officers, and $1.3 \%$ of respondents engaged in other positions.

To determine the mean value of the study variables result whether the value is strongly agreed or strongly disagree, the researcher used as a reference set by AlSayaad et al. (2006). According to their specification based on Table 4, the mean value of self-efficacy 3.81 at the level of "agree", the autonomy mean value 3.25 lies at the "neutral" level, the supervisors support mean value 3.21 at the level of "neutral", the mean of job complexity 3.69 at the level of "agree", the last independent variable role

Table 2 Reliability of the study variables. Source: own survey (2020)

\begin{tabular}{lll}
\hline Variables & Number of items & Cronbach's alpha \\
\hline Employees creativity & 8 & .795 \\
Autonomy & 5 & .853 \\
Supervisor support & 5 & .822 \\
Role ambiguity & 5 & .637 \\
Self-efficacy & 7 & .825 \\
Job complexity & 5 & .845
\end{tabular}


Table 3 Descriptive statistic of the demographic variables. Source: own survey (2020)

\begin{tabular}{|c|c|c|c|}
\hline Variables & Frequency & Percent & $\begin{array}{l}\text { Cumulative } \\
\text { percent }\end{array}$ \\
\hline \multicolumn{4}{|l|}{ Sex of respondents } \\
\hline Male & 131 & 82.4 & 82.4 \\
\hline Female & 28 & 17.6 & 100.0 \\
\hline Total & 159 & 100.0 & \\
\hline \multicolumn{4}{|l|}{ Age of workers } \\
\hline Below 25 & 4 & 2.5 & 2.5 \\
\hline $25-34$ & 102 & 64.2 & 66.7 \\
\hline $35-44$ & 52 & 32.7 & 99.4 \\
\hline $45-54$ & 1 & 6 & 100.0 \\
\hline Total & 159 & 100.0 & \\
\hline \multicolumn{4}{|l|}{ Education background } \\
\hline Diploma & 10 & 6.3 & 6.3 \\
\hline Bachelor & 127 & 79.9 & 86.2 \\
\hline Master & 22 & 13.8 & 100.0 \\
\hline Total & 159 & 100.0 & \\
\hline \multicolumn{4}{|l|}{ Workers experience } \\
\hline Below 2 years & 1 & .6 & 6 \\
\hline 2-4 years & 58 & 36.5 & 37.1 \\
\hline 4-6 years & 59 & 37.1 & 74.2 \\
\hline Above 6 years & 41 & 25.8 & 100.0 \\
\hline Total & 159 & 100.0 & \\
\hline \multicolumn{4}{|l|}{ Position of workers } \\
\hline Branch Manager & 2 & 1.3 & 1.3 \\
\hline Business Manager & 7 & 4.4 & 5.7 \\
\hline Senior Banking business officer & 25 & 15.7 & 21.4 \\
\hline Banking business officer & 97 & 61.0 & 82.4 \\
\hline Business operation officer & 26 & 16.4 & 98.7 \\
\hline Others & 2 & 1.3 & 100.0 \\
\hline Total & 159 & 100.0 & \\
\hline
\end{tabular}

Table 4 Descriptive statistics. Source: own survey (2020)

\begin{tabular}{llcc}
\hline Variables & N & Mean & Std. deviation \\
\hline Self-efficacy (SE) & 159 & 3.8131 & .83066 \\
Autonomy (AT) & 159 & 3.2516 & .97233 \\
Supervisor support (SS) & 159 & 3.2050 & .98494 \\
Job complexity (JC) & 159 & 3.6956 & .91287 \\
Role ambiguity (RA) & 159 & 3.7270 & 1.22865 \\
Employees' creativity (EC) & 159 & 3.2846 & .90597 \\
\hline
\end{tabular}

ambiguity mean value 3.72 lies at "agree", and the dependent variable employees' creativity mean value became at the level of "neutral".

\section{Effect analysis of the study}

As can be seen in Table 5, the correlation between employees' creativity and the optimal linear combination of the independent variables is .611 , as indicated by multiple $R$. The $R$ 
Table 5 Model summary. Source: own survey (2020)

\begin{tabular}{|c|c|c|c|c|c|c|c|c|c|}
\hline \multirow[t]{2}{*}{ Model } & \multirow[t]{2}{*}{$R$} & \multirow[t]{2}{*}{$R$ square } & \multirow{2}{*}{$\begin{array}{l}\text { Adjusted } R \\
\text { square }\end{array}$} & \multirow{2}{*}{$\begin{array}{l}\text { Std. error of } \\
\text { the estimate }\end{array}$} & \multicolumn{5}{|c|}{ Change statistics } \\
\hline & & & & & $\begin{array}{l}R \text { square } \\
\text { change }\end{array}$ & F change & $d f 1$ & $d f 2$ & Sig. $\boldsymbol{F}$ change \\
\hline 1 & $.611^{\mathrm{a}}$ & .373 & .353 & .72886 & .373 & 18.223 & 5 & 153 & .000 \\
\hline
\end{tabular}

Table 6 Coefficient of study variables. Source: own survey (2020)

\begin{tabular}{lcccrr}
\hline Model & \multicolumn{2}{l}{ Unstandardized coefficients } & $\begin{array}{l}\text { Standardized } \\
\text { coefficients } \\
\text { Beta }\end{array}$ & $T$ & Sig \\
\cline { 2 - 4 } & \multicolumn{1}{c}{$\boldsymbol{B}$} & Std. error & & & \\
\hline 1 & 1.344 & .327 & & 4.104 & .000 \\
(Constant) & -.019 & .104 & -.018 & -.185 & .853 \\
Self-efficacy (SE) & .336 & .080 & .361 & 4.192 & .000 \\
Autonomy (AT) & .227 & .087 & .246 & 2.606 & .010 \\
Supervisor support (SS) & -.089 & .087 & -.090 & -1.029 & .305 \\
Job complexity (JC) & .141 & .061 & .191 & 2.314 & .022 \\
Role ambiguity (RA) & & & & &
\end{tabular}

${ }^{a}$ Dependent variable: employees' creativity

square, which is the degree to explain the variation in the dependent variable (employees' creativity in this case) by the independent variables which include the model. Thus, the value of adjusted $R$ square is .353, which are all independent variables included the model explained $35.3 \%$ percent of the total variance in employees' creativity, and the remaining $64.7 \%$ is because of other unknown variables which are not included in this study.

Furthermore, the ANOVA analysis indicates the $F$-test of the overall significance of the model. Therefore, in this study, the value of the $F$-test was $(F=18.223, d f 1=5, d f 2=153$, $p<.01)$, which is the model is a significant fit of the data overall.

As regards regression analysis as shown in Table 6, the result of multiple regressions shows that three variables are statistically significant. The regression coefficient for autonomy was positive and statistically significant $(\beta=.336)$ with $t$-value $=4.192$, $p$-value <.001), implying that autonomy can affect the creativity of employees in the banks. Employees have the freedom to undertake their routine task and create a new system for the banks. The other variable able to predict the creativity of employees in the bank is supportive supervision by respective supervisors. This variable affects positively and statistically significant at $\beta=.227$, with a $t$ value $=2.606, p$-value $<.005$. The regression result reveals that supervisors' support plays a significant role in enhancing employees' creativity in the bank. The last variable that significantly affects the creativity of employees is role ambiguity. The regression result indicates that role ambiguity has a positive effect and statistically significant at $\beta=.141$ with a $t$ value $=2.314, p=.022$. This result revealed that there is a clear and specified role given for employees.

The remaining variables, self-efficacy and job complexity, do not significantly affect the creativity of employees' in the bank. Therefore, the final model of the study would be: 
Employees' creativity $=1.344+.336 \mathrm{AT}+.227 \mathrm{SS}+.141 \mathrm{RA}$.

From the significant variables of the study supervisor support affects highly, autonomy moderately, and role ambiguity lastly influencing the creativity of the bank employees' at the work place.

\section{Discussion}

At the workplace, workers should be free from any negative intervention from the respective or immediate boss, supervisors, and managers to bring new creativity and innovations to their organization. The autonomy of the employees in the study area banks significantly affects the creativity of employees. The regression result can be evidence that employees have a bit of freedom to perform their duties and responsibility freely and they have a chance to create new systems, procedures, and techniques for the bank. Employee's freedom has a positive effect on creativity at the work place. This study result for the variable of autonomy is consistent with the finding of Çekmecelioğlu and Günsel (2011). It gives employees to make the decision and determining how to accomplish activities and enhance the creativity of employees at workplace. Therefore, the study result is also consistent with the finding of Hassan et al. (2013).

Continuous support from the supervisor is a means to create successful workers in the work place. The supervisor provides continuous feedback for the workers based on their gaps and inabilities during their operation. The regression result of the study indicates that supervisors' support can be an instigating factor for employees' creativity at the work place with a statistically significance level.

During the supervision time, the supervisors should be alert to identify the real gap that becomes a hindrance to the creativity of employees. That may give an insight into how the workers will create new ways and techniques for the bank (Hassan et al., 2013). This study result is similar to the finding of An et al. (2015) because their finding and this study supervisor's support positively affects the creativity of workers with statistical significant level.

A vague role at the workplace will enhance the stress of workers, may stop them from creating new products and services. As much as possible the managers should identify the role of workers in the work place (Tang \& Chang, 2010). The study result revealed that role ambiguity has a positive effect on the creativity of workers in the bank. It meant that officers, supervisors, and other workers are assigned clearly defined work and the employees become free from any unclear role in the bank. Çekmecelioğlu and Günsel (2011) suggested that when there are free and clear roles for workers in the workplace, the creativity of employees will enhanced. This statement is supported by this study result and also consistent with the finding of Tang and Chang (2010).

\section{Analysis of open-ended question responses}

\section{Challenges of creativity in the bank}

The researcher prepared an open-ended question to understand the feeling of employees in the bank about the challenges of creativity. According to the response of the respondents listed the challenges that faced them in the bank to become creative. 
Among the challenges, there is a routine task, a shortage of time to read and scan the environment to create a new system, product, and other services for the bank. Respondents also replied that there is no system to motivate and to encourage creative workers. For creative workers, there is no promotion system to transfer from one level to the next level in the bank and the branch managers do not accept new creative ideas arise from the employee side. The other factor that affects employee creativity, the bank administration system is too centralized, bureaucratic system, system rigidity, lack of integrity, absence of isolated department to support creativity, and there is poor communication (only from top to down). The other factors arise from the employee side. Among the challenges, employees are reluctant to create and to accept innovations and did not share experiences from senior staff, and lack of commitment to creating new technologies and systems for the banks. Furthermore, the bank is limited to participate in research and development activities.

\section{Conclusions}

There are several factors that affect the creativity of employees at the workplace. In this study, the researcher examined five variables that affect the employees' creativity. Among the variables self-efficacy, autonomy, supervisor's support, job complexity, and role ambiguity were examined properly. Based on the result and discussion of the study, the researcher reaches the following conclusions:

When the autonomy of employees' is ensured by the organization at work place, it helps to increase creativity and innovation, especially in the stiff competition of the bank industry. The study variable autonomy significantly affects positively the employees' creativity in the commercial bank Ethiopia.

The support of supervisors has a direct relationship with the creativity of employees at the work place. The supervisors may provide continuous feedback for workers to correct their mistakes during the creativity process. This may help the employee to create a new technique system, products, and service. This study regression result assured that supervisors support statistically significant to affect the creativity of the employees in the bank.

Every organization's role should be clearly defined for all workers, supervisors, and managers to facilitate the creativity of the workers. Because the employees become free from any third person intervention in their work place. When the roles are ambiguous, the employees' may be frustrated to create new things. The study result revealed that role ambiguity significantly affects the employees' creativity in the bank.

\section{Future implications of the study}

This study was conducted at the institutional level to examine the creativity-related challenges and factors that may affect workers at the work place. The study result will indicate to bank managers at which factor they need to focus on to enhance creativity and innovativeness of their workers. It is known that creativity leads workers to become innovative and help transform the organization to an advanced level. This study result also helps researchers to study in detail related with creativity at the work place. 
The future research line will attempt to:

- Explore other factors that affect workers creativity such as work environment, incentives, motivations of workers, technological factors, competition among banks, and cultural variables.

- Comparative study between private banks and the government banks to assess the creativity of employees.

- Examining the innovativeness of workers in the bank.

\section{Appendix}

See Table 7.

Table 7 List of variables, number of items and sources of the items

\begin{tabular}{llll}
\hline S. no. & Variables & Number of items & Source of the items \\
\hline 1. & Employees creativity & 8 & Ekmekçi and Tekin (2011) \\
2. & Supervisor's support & 5 & \\
3. & Role ambiguity & 5 & Rizzo et al. (1970) \\
4. & Self-efficacy & 7 & Riggs et al. (1994) \\
5. & Job complexity & 5 & Morgeson and Humphrey (2006) \\
\hline
\end{tabular}

\section{Abbreviations}

SE: Self-efficacy; AT: Autonomy; SS: Supervisor support; JC: Job complexity; RA: Role ambiguity; EC: Employees' creativity.

\section{Acknowledgements}

I am grateful to all anonymous reviewers, my respondents, and bank staffs who helped me by coordinating the data collection procedures. Among the staffs who support me, Solomon T. from Piaza (Woldia) main branch, Elias from Adago branch, Yonas from Gubalafto branch, and Me'aza and her friend from Yeju Genet branch are thanked.

\section{Authors' contributions}

The research was done independently. I have carried out the whole work of the research. The author read and approved the final manuscript.

\section{Funding}

The author has not received a fund from any organizations and individuals.

\section{Availability of data and materials}

All data are included in the manuscript.

\section{Declarations}

Competing interests

The author declares that there are no competing interests.

Received: 20 November 2020 Accepted: 15 September 2021

Published online: 20 October 2021

\section{References}

Abrar, M. (2016). Teaching English problems: An analysis of EFL primary school teachers in Kuala Tungkal. In The 16th Indonesian Scholars International Convention (pp. 94-101).

Antoniades, A. C. (1990). Poetics of architecture: Theory of design. Van Nostrand Reinhold Company.

Agu, O. L. (2015). Work engagement, organizational commitment, self efficacy and organizational growth: A literature review. Information Impact: Journal of Information and Knowledge Management, 6(1), 14-29. 
Alhajri, A. (2018). Creativity and innovation in google. International Journal of Science and Research, 7(2), 438-442. Al-Sayaad, J., Rabea, A., \& Samrah, A. (2006). Statistics for economics and administration studies. Jeddah: Dar Hafez.

An, N., Anh, N., Chinh, D., Hong, L., Son, L., \& Tuan, N. (2015). Factors affecting employee creativity \& its impact on organizational innovation capability in state owned banks in Hanoi, Vietnam. In Proceedings of 47th the IIER international conference (pp. 23-30).

Beheshtifar, M., \& Zare, E. (2013). Employee creativity: A compulsory factor in organizations. Interdisciplinary Journal of Contemporary Research in Business, 5(2), 242-247.

Boden, M. A. (1998). Creativity and artificial intelligence. Artificial intelligence, 103(1-2), 347-356.

Çekmecelioğlu, H. G., \& Günsel, A. (2011). Promoting creativity among employees of mature industries: The effects of autonomy and role stress on creative behaviors and job performance. Procedia-Social and Behavioral Sciences, 24, 889-895.

Daemei, A. B., \& Safari, H. (2018). Factors affecting creativity in the architectural education process based on computeraided design. Frontiers of Architectural Research, 7(1), 100-106.

Dehnavieh, R., Hasanzadeh, E., Mehralhasani, M. H., Pour, H. I., Shahheidari, M., \& Hekmat, S. N. (2010). Factors influencing creativity and innovation of the senior managers of Iran University of Medical Sciences-2010. Research Journal of Biological Sciences, 5(11), 708-712.

Doshmanziari, E. (2018). Identifying and ranking factors effecting creativity and innovation through employees training in Kian Tire Industrial Plant, Iran. International Journal of Economics, Commerce and Management 525-539. http://ijecm. co.uk/.

Egan, T. M. (2005). Factors influencing individual creativity in the workplace: An examination of quantitative empirical research. Advances in Developing Human Resources, 7(2), 160-181.

Ekmekçi, A. K., \&Tekin, B. (2011). The examination of the relationship between creativity and work environment factors with a research in white-goods sector in Turkey. Öneri Dergisi, 9(35), 51-74.

ElMelegy, A. R., Mohiuddin, Q., Boronico, J., \& Maasher, A. A. (2016). Fostering creativity in creative environments: An empirical study of Saudi Architectural Firms. Contemporary Management Research, 12(1), 89-120.

Hakimian, F., Farid, H., Ismail, M. N., \& Nair, P. K. (2016). Importance of commitment in encouraging employees' innovative behaviour. Asia-Pacific Journal of Business Administration, 8, 70-83.

Hashim, K. L. (2020). Factors influencing innovative work behavior (IWB) of civil servants in Malaysian Public Service Organizations: a conceptual study. Asian Journal of Research in Business and Management, 2(2), 187-196.

Hassan, M. U., Malik, A. A., Hasnain, A., Faiz, M. F., \& Abbas, J. (2013). Measuring employee creativity and its impact on organization innovation capability and performance in the banking sector of Pakistan. World Applied Sciences Journal, 24(7), 949-959.

Jaiswal, N. K., \& Dhar, R. L. (2015). Transformational leadership, innovation climate, creative self-efficacy and employee creativity: A multilevel study. International Journal of Hospitality Management, 51, 30-41.

Morgeson, F. P., \& Humphrey, S. E. (2006). The Work Design Questionnaire (WDQ): Developing and validating a comprehensive measure for assessing job design and the nature of work. Journal of Applied Psychology, 91(6), 1321.

Purnama, Y. H., Tjahjono, H. K., Elqadri, Z. M., \& Prajogo, W. (2020). Innovative work behavior: The role of self-efficacy and organizational climates. Springer.

Riggs, M., Warka, J., Babasa, B., Betancourt, R., \& Hooker, S. (1994). Development and validation of self-efficacy and outcome expectancy scales for job-related applications. Educational and Psychological Measurement, 54(3), 793-802.

Rizzo, J. R., House, R. J., \& Lirtzman, S. I. (1970). Role conflict and ambiguity in complex organizations. Administrative Science Quarterly, 15, 150-163.

Sadeghi, A., \& Ofoghi, N. (2011). The psychological factors affecting students' Creativity Inside the Class (CIC) (case study the University of Guilan, Iran). Procedia-Social and Behavioral Sciences, 15, 263-270.

Su, W., Lin, X., \& Ding, H. (2017). The influence of supervisor developmental feedback on employee innovative behavior: A moderated mediation model. Frontiers in Psychology, 10(July), 1-12.

Tang, Y.T., \& Chang, C. H. (2010). Impact of role ambiguity and role conflict on employee creativity. African Journal of Business Management, 4(6), 869-881.

Wooldridge, J. M. (2013). Introductory econometrics: A modern approach (5th ed.). Cengage Learning.

Zarei, H. (1997). Creativity and innovation. Managent Science, 24, 1-12 (in persian).

Zikmund, B. C. (2011). Business research methods (8th ed.). William G. Zikmund.

\section{Publisher's Note}

Springer Nature remains neutral with regard to jurisdictional claims in published maps and institutional affiliations. 